\title{
Pelatihan Penyusunan Perangkat Pembelajaran Berbasis IT
}

\author{
Agung Pranoto ${ }^{*}$, Rini Damayanti ${ }^{*}$, Roely Ardiansyah ${ }^{3}, \mathrm{Kaswadi}^{4}$, Sueb $^{5}$ \\ 1,2,3,4,5 Universitas Wijaya Kusuma Surabaya, Indonesia \\ *Corresponding Author: rinidamayanti_fbs@uwks.ac.id
}

\begin{abstract}
Info Artikel
Diterima : 20/01/2022

Direvisi: $27 / 01 / 2022$

Disetujui: 30/01/2022

Abstract. The Community Service Program (Penmas) aims to improve the ability of teachers in terms of learning tools, improve the ability of teachers to use IT, and improve teacher administration skills. The implementation of Penmas is preceded by providing information to the Chair of the Foundation about the training activities that will be carried out, giving invitations to teachers who will be training participants, carrying out training from January 19-20 2022, and making reports on the results of implementing activities. The materials presented during the training were: 1) Administrative urgency for educators, 2) IT-based learning tools. Participants also get guidance on writing learning tools in tutorial activities and practice writing learning tools. The training participants were 40 SMK and MA Tanada Foundation teachers. The conclusions from the implementation of the community service program "Workshop on Strategies for Developing IT-Based Learning Devices as an Effort for the Efficiency and Effectiveness of Teacher Tasks at the Tanada Waru Sidoarjo Foundation" are the increased willingness of participants to make learning tools, increased ability of participants in making IT-based learning tools and increased ability to integrate IT on learning.
\end{abstract}

Keywords: Training, Device, Learning, IT

\begin{abstract}
Abstrak. Program Pengabdian Pada Masyarakat (Penmas) yang dilakukan bertujuan untuk meningkatkan kemampuan guru dalam hal perangkat pembelajaran, meningkatkan kemampuan guru dalam mempergunakan IT, dan meningkatkan kemampuan administrasi guru. Pelaksanaan Penmas didahului dengan pemberian informasi kepada Ketua Yayasan tentang kegiatan pelatihan yang akan dilakukan, memberikan undangan kepada guru yang akan menjadi peserta pelatihan, melaksanakan pelatihan mulai 19-20 Januari 2022, dan membuat laporan hasil pelaksanaan kegiatan. Materi yang disampaikan pada saat pelatihan ialah: 1) Urgensi administrasi untuk tenaga pendidik, 2) Perangkat Pembelajaran berbasis IT. Peserta juga mendapatkan bimbingan penulisan perangkat pembelajaran pada kegiatan tutorial dan praktik penulisan perangkat pembelajaran. Peserta pelatihan sebanyak 40 guru SMK dan MA Yayasan Tanada. Simpulan dari pelaksanaan program pengabdian masyarakat "Workshop Strategi Penyusunan Perangkat Pembelajaran Berbasis IT sebagai Upaya Efisiensi dan Efektivitas Tugas Guru di Yayasan Tanada Waru Sidoarjo" ialah meningkatnya kemauan peserta dalam membuat perangkat pembelajaran, meningkatnya kemampuan peserta dalam membuat perangkat pembelajaran berbasis IT dan meningkatnya kemampuan mengintegrasikan IT pada pembelajaran.
\end{abstract}

Kata Kunci: Pelatihan, Perangkat, Pembelajaran, IT

How to Cite: Pranoto, A., Damayanti, R., Ardiansyah, R., Kaswadi, K., \& Sueb, S. (2022). Pelatihan Penyusunan Perangkat Pembelajaran Berbasis IT. Prima Abdika: Jurnal Pengabdian Masyarakat, 2(1), 2431. https: / / doi.org/10.37478/abdika.v2i1.1604

cc (i) (2) Copyright (c) 2022 Agung Pranoto, Rini Damayanti, Roely Ardiansyah, Kaswadi, Sueb. This work

\section{Pendahuluan}

Dalam rangka melaksanakan Tridarma Perguruan Tinggi, Program Studi Pendidikan Bahasa dan Sastra Indonesia, Fakultas Bahasa dan Sains, Universitas Wijaya Kusuma Surabaya merancang kegiatan pengabdian kepada masyarakat (penmas) secara berkala, disesuaikan dengan alokasi dana yang diberikan oleh universitas. Kegiatan penmas tersebut dilaksanakan satu kali dalam satu semester atau dua kali dalam satu tahun akademik. Bentuk dan materi kegiatan penmas disesuaikan dengan bidang keahlian dosen di program studi, yaitu berkaitan dengan Pendidikan Bahasa Indonesia.

Kegiatan penmas kali ini berkaitan dengan pengembangan profesi guru. Pengembangan profesi guru adalah kegiatan guru dalam rangka pengamalan ilmu pengetahuan, teknologi dan keterampilan untuk peningkatan mutu, baik bagi proses belajar mengajar dan profesionalisme tenaga kependidikan lainnya 
maupun dalam rangka menghasilkan sesuatu yang bermanfaat bagi pendidikan dan kebudayaan. Adapun kegiatan pengembangan profesi yang dimaksud adalah 1.) Membuat perangkat pembelajaran, 2.) menemukan teknologi di bidang pendidikan, 3.) membuat alat pelajaran/alat peraga atau alat bimbingan, 4.) Menciptakan karya tulis ilmiah, dan mengikuti kegiatan pengembangan kurikulum, (Depdiknas, 2001: 1). Maka perangkat pembelajaran merupakan syarat mutlak bagi guru.

Perangkat pembelajaran merupakan suatu perencanaan yang dipergunakan dalam proses pembelajaran. Oleh karena itu, Kunandar (2014) menjelaskan bahwa "setiap guru pada satuan pendidikan berkewajiban menyusun perangkat pembelajaran yang lengkap, sistematis agar pembelajaran dapat berlangsung secara interaktif, inspiratif, menyenangkan, menantang, memotivasi peserta didik untuk berpatisipasi aktif". Perangkat pembelajaran memiliki peranan penting bagi seorang guru sebelum memulai proses pembelajaran. Perangkat pembelajaran yang diperlukan dalam mengelola proses belajar mengajar dapat berupa: silabus, Rencana Pelaksanaan Pembelajaran (RPP) dan Lembar Aktivitas Siswa (LAS).

Perangkat yang digunakan dalam proses pembelajaran disebut dengan perangkat pembelajaran. Ibrahim (dalam Trianto, 2010) menyatakan bahwa "perangkat pembelajaran yang diperlukan dalam mengelola proses belajar mengajar dapat berupa silabus, RPP, Lembar Kegiatan Siswa (LKS), Instrumen Evaluasi atau Tes Hasil Belajar (THB), serta Media Alat Peraga pembelajaran". Jadi, Perangkat Pembelajaran dapat diartikan sebagai alat kelengkapan yang digunakan untuk membantu pembelajaran. Pada penelitian ini perangkat pembelajaran yang digunakan terdiri dari silabus, RPP dan LAS.

Pembuatan perangkat pembelajaran oleh guru masih sangat terbatas jumlahnya. Nampak bahwa para guru kurang mempunyai keinginan untuk perangkat pembelajaran berbasis IT karena kurang pengetahuan dan kemampuan tentang IT. Berdasarkan uraian diatas, dipertimbangkan perlu dilakukan kegiatan workshop strategi penyusunan perangkat pembelajaran berbasis IT bagi para guru, yang karena keterbatasan waktu, tenaga dan pengetahuan serta kemampuan guru-guru, dibatasi para guru SMK dan MA Yayasan Tanada. Pelatihan difokuskan pada peningkatan kemauan (motivasi) dan kemampuan guru membuat perangkat pembelajaran berbasis IT.

Berdasarkan situasi tersebut Jurusan Pendidikan Bahasa Indonesia, Universitas Wijaya Kusuma Surabaya bermaksud memberikan workshop kepada guru-guru SMK dan MA Yayasan Tanada dengan membekali dan memberikan informasi pembuatan perangkat pembelajaran yang baik dan benar. Kegiatan Pengabdian masyarakat ini bertujuan untuk memberikan workshop kepada guru-guru SMK dan MA Yayasan Tanada tentang perangkat pembelajaran berbasis IT.

\section{Metode Pelaksanaan}

Metode kegiatan Pengabdian Masyarakat ini dilakukan melalui kegiatan pelatihan pembuatan perangkat pembelajaran berbasis IT. Adapun proses pelaksanaan program ini adalah melalui tahap-tahap sebagai berikut:

\section{Tahap Persiapan}

Tahap persiapan yang dilakukan meliputi : 
Adanya permintaan pelatihan dari sekolah sehingga diadakan survey lokasi pengabdian kepada masyarakat. Kemudian diadakan pemantapan dan penentuan jadwal kegiatan. Penyusunan bahan/materi pelatihan, yang meliputi: pembuatan makalah untuk kegiatan pelatihan, penyiapan bahan dan alat untuk kegiatan pelatihan pembuatan perangkat pembelajaran. Kepala sekolah dan tim penmas pun memutuskan menggunakan metode luring untuk pelatihan dengan catatan peserta terbatas dan mematuhi prokes. Luring adalah akronim luar jaringan, terhubung secara tatap muka (Mahsun, 2011). Metode ini dilakukan dengan bimbingan dan konsultasi secara luring oleh para tim pelaksana. Bimbingan dilakukan secara menyeluruh agar peserta dapat membuat perangkat pembelajaran secara baik dan benar.

\section{Tahap Pelaksanaan Pelatihan}

Kegiatan Program Pengabdian Pada Masyarakat dilaksanakan selama dua hari, yaitu tanggal 19 dan 20 Januari 2022 dengan 6 sesi yakni sesi I penyampaian teori mengenai strategi penyusunan perangkat pembelajaran, sesi II digunakan untuk materi perangkat pembelajaran berbasik TIK, sesi III bahan ajar berbasis TIK, sesi IV terkait media pembelajaran interaktif, sesi $\mathrm{V}$ evaluasi berbasis teknologi dan sesi $\mathrm{V}$ praktik penyusunan perangkat pembelajaran sekaligus konsultasi dan pendampingan.

\section{Metode Pelatihan}

Metode pelatihan secara luring. Berupa pemberian materi, pelatihan, pendampingan dan konsultasi. Bimbingan dilakukan secara menyeluruh agar peserta dapat membuat perangkat pembelajaran secara baik dan benar.

\section{Hasil dan Pembahasan}

Guru Sebagai Profesi Mengacu pada Undang-undang guru dan dosen Nomor 14 Tahun 2005 dijelaskan pada pasal 1 ayat 1 bahwa guru adalah pendidik profesional dengan tugas utama mendidik, mengajar, membimbing, mengarahkan, melatih, menilai dan mengevaluasi peserta didik pada pendidikan anak usia dini jalur pendidikan formal, pendidikan dasar dan pendidikan menengah. Kemampuan melaksanakan tugas-tugas yang menjadi tanggung jawab guru merupakan sebagian dari kompetensi profesionalisme guru. Depdiknas (2001) mengemukakan tiga tugas guru sebagai profesi meliputi mendidik, mengajar dan melatih. (a) mendidik berarti meneruskan dan mengembangkan nilai-nilai hidup, (b) mengajar berarti meneruskan dan mengembangkan ilmu pengetahuan, (c) melatih berarti mengembangkan keterampilan-keterampilan pada siswa.

Yudha (2020) mengemukakan ada lima tugas dan tanggung jawab pengajar, yakni tanggung jawab dalam (a) pengajaran, (b) bimbingan belajar, (c) pengembangan kurikulum, (d) pengembangan profesinya, dan (e) pembinaan kerjasama dengan masyarakat. Sudarwan (2013) mengemukakan tiga macam tugas utama guru, yakni (a) merencanakan tujuan proses belajar mengajar, bahan pelajaran, proses belajar mengajar yang efektif dan efisien, menggunakan alat ukur untuk mencapai tujuan pengajaran tercapai atau tidak, (b) melaksanakan pengajaran, (c) memberikan balikan (umpan balik). Berdasarkan beberapa pendapat para ahli tersebut dapat disimpulkan tentang 
tugas guru yaitu (a) tugas pengajaran, bimbingan dan latihan kepada siswa, (b) pengembangan profesi guru, (c) pengabdian masyarakat.

Untuk dapat melaksanakan tugas dan tanggung jawab di atas, seorang guru dituntut memiliki beberapa kemampuan dan keterampilan tertentu. Kemampuan dan keterampilan tersebut sebagai bagian dari kompetensi profesionalisme guru. Kompetensi merupakan suatu kemampuan yang mutlak dimiliki oleh guru agar tugasnya sebagai pendidik dapat terlaksana dengan baik. Pengertian dasar kompetensi (competency) yakni kemampuan atau kecakapan. Menurut Usman (2000), kompetensi merupakan perilaku yang rasional untuk mencapai tujuan yang dipersyaratkan sesuai dengan kondisi yang diharapkan. Sedang yang dimaksud dengan kompetensi guru (teacher competency) merupakan kemampuan seorang guru dalam melaksanakan kewajiban secara bertanggung jawab dan layak.

Dari pendapat tersebut dapat disimpulkan bahwa kompetensi guru merupakan kemampuan guru dalam melaksanakan tugas-tugas sebagai pengajar yang dilakukan secara bertanggung jawab dan layak. Sudjana (2000) mengemukakan empat jenis kompetensi tenaga pengajar, yakni (a) mempunyai pengetahuan belajar dan tingkah laku manusia, (b) menguasai bidang ilmu yang dibinanya, (c) memiliki sikap yang tepat tentang dirinya sendiri dan teman sejawat serta bidang ilmunya, (d) keterampilan mengajar.

Pada dasarnya profesi guru adalah profesi yang sedang tumbuh. Walaupun ada yang berpendapat bahwa guru adalah jabatan semiprofesional, namun sebenarnya lebih dari itu. Usaha profesionalisasi merupakan hal yang tidak perlu ditawar-tawar lagi karena uniknya profesi guru. Profesi guru harus memiliki berbagai kompetensi seperti kompetensi profesional, personal, dan sosial. Seseorang dianggap profesional apabila mampu mengerjakan tugasnya dengan selalu berpegang teguh pada etika kerja, independent (bebas dari tekanan pihak luar), cepat (produktif), tepat (efektif), efisien dan inovatif serta didasarkan pada prinsip-prinsip pelayanan prima yang didasarkan pada unsur-unsur ilmu atau teori yang sistematis, kewenangan profesional, pengakuan masyarakat dan kode etik yang regulatif.

Pengembangan wawasan dapat dilakukan melalui forum pertemuan profesi, pelatihan ataupun upaya pengembangan dan belajar secara mandiri. Sejalan dengan hal di atas, seorang guru harus terus meningkatkan profesionalismenya melalui berbagai kegiatan yang dapat mengembangkan kemampuannya dalam mengelola pembelajaran maupun kemampuan lain dalam upaya menjadikan peserta didik memiliki keterampilan belajar, mencakup keterampilan dalam memperoleh pengetahuan (learning to know), keterampilan dalam pengembangan jati diri (learning to be), keterampilan dalam pelaksanaan tugas-tugas tertentu (learning to do), dan keterampilan untuk dapat hidup berdampingan dengan sesama secara harmonis (learning to live together). Berangkat dari makna dan syarat-syarat profesi sebagaimana dijelaskan pada bagian terdahulu, maka dalam rangka pengembangan profesionalisme guru secara berkelanjutan perlu melaksanakan pelatihan pembuatan perangkat pembelajaran ini.

Program pengabdian masyarakat dengan judul "Workshop Strategi Penyusunan Perangkat Pembelajaran Berbasis IT sebagai Upaya Efisiensi dan Efektivitas Tugas Guru di Yayasan Tanada Waru Sidoarjo " telah berjalan dengan baik. Pelatihan diikuti oleh 40 peserta dengan rincian 20 guru SMK 
Tanada dan 20 guru MA Tanada pada 19 - 20 Januari 2021. Kegiatan pelatihan terdiri dari penyampaian materi selama 10 jam, dan praktik penyusunan perangkat pembelajaran selama 6 jam. Materi yang disampaikan yaitu: penyampaian teori mengenai strategi penyusunan perangkat pembelajaran, perangkat pembelajaran berbasik TIK, bahan ajar berbasis TIK, media pembelajaran interaktif, evaluasi berbasis teknologi dan praktik penyusunan perangkat pembelajaran sekaligus konsultasi dan pendampingan. Pemateri terdiri dari 5 orang dosen yang berasal dari tim Penmas Prodi Pendidikan Bahasa Indonesia, Universitas Wijaya Kusuma Surabaya. Sedangkan kegiatan tutorial dilaksanakan dengan setiap peserta memaparkan perangkat pembelajaran yang pernah dibuat sebelumnya. Selanjutnya, dosen pendamping memberikan masukan/saran untuk perbaikan. Sementara untuk praktik pembuatan perangkat pembelajaran, guru-guru diminta untuk membuat perangkat berbasis IT.

Setelah dilaksanakannya pelatihan, hasil yang didapatkan ialah:

1. Meningkatnya kemauan peserta dalam membuat perangkat pembelajaran berupa silabus, RPP, Lembar Kegiatan Siswa (LKS), Instrumen Evaluasi atau Tes Hasil Belajar (THB), serta Media Alat Peraga pembelajaran dan terintegrasi dengan IT

2.Meningkatnya kemampuan peserta dalam membuat perangkat pembelajaran berbasis IT meliputi kemampuan:

a. Menyusun RPP,

b. Menyusun bahan ajar dan media pembelajaran berbasis teknologi,

c. Membuat alat evaluasi yang mempergunakan teknologi,

3. Meningkatnya kemampuan mengintegrasikan IT pada pembelajaran.

Program pengabdian masyarakat dengan judul "Workshop Strategi Penyusunan Perangkat Pembelajaran Berbasis IT sebagai Upaya Efisiensi dan Efektivitas Tugas Guru di Yayasan Tanada Waru Sidoarjo" telah berjalan dengan baik. Pelatihan diikuti oleh 40 peserta. Kegiatan pelatihan terdiri dari penyampaian materi, tutorial perangkat pembelajaran, dan praktik pembuatan perangkat pembelajaran berbasis IT.

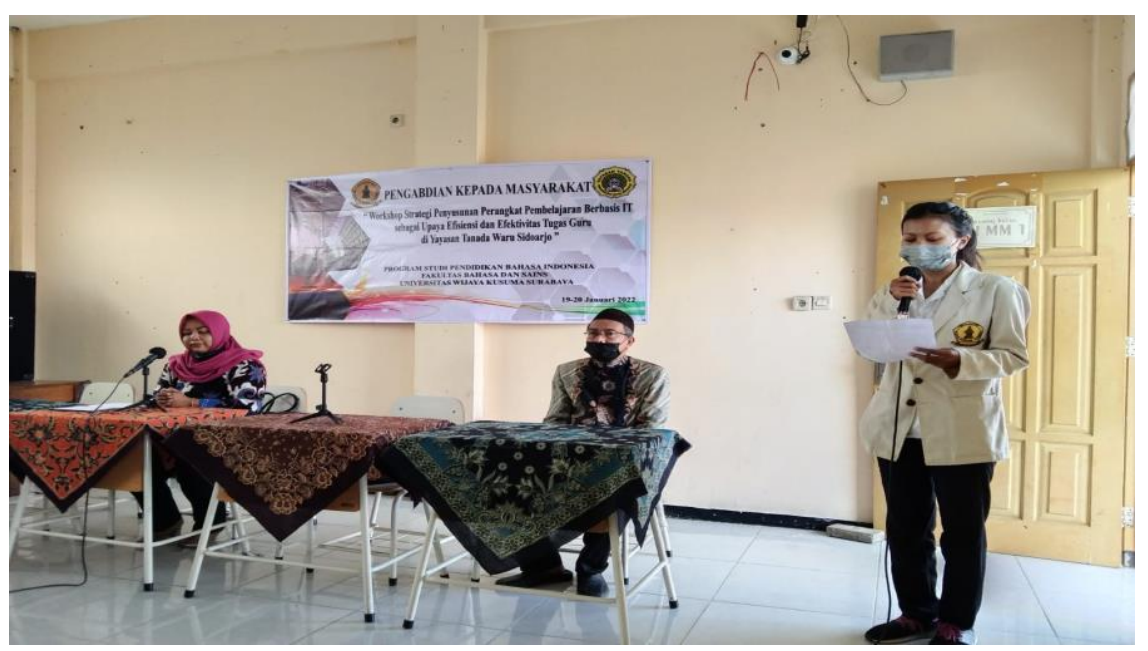

Gambar 1. Pembukaan Workshop Strategi Penyusunan Perangkat Pembelajaran Berbasis IT sebagai Upaya Efisiensi dan Efektivitas Tugas Guru di Yayasan Tanada Waru Sidoarjo 
Pelaksanaan pelatihan di awali dengan pembukaan secara luring di aula Yayasan Tanada Waru Sidoarjo. Kemudian peserta diberikan materi dengan narasumber dosen Universitas Wijaya Kusuma Surabaya. Setelah pembukaan, dilanjutkan dengan sesi 1 penyampaian materi pertama.

Materi pertama yaitu Strategi Penyusunan Perangkat Pembelajaran. Materi disampaikan oleh Drs. Agung Pranoto, M.Pd. Materi yang disampaikan meliputi pentingnya strategi untuk efektivitas dan efisiensi pembuatan perangkat. Pemateri merupakan salah satu Dosen di Jurusan Pendidikan Bahasa Indonesia yang telah memiliki pengalaman sangat banyak serta Jabatan/Golongan yang tinggi sehingga sangat relevan dengan materi yang disampaikan.

Setelah penyampaian materi pertama dilanjutkan dengan penyampaian materi oleh pemateri kedua. Materi ke-2 yaitu Perangkat Pembelajaran berbasis IT. Materi ke-2 disampaikan oleh Dr. Roely Ardiansyah, M.Pd. Materi ke-3 Bahan Ajar berbasis TIK disampaikan oleh Dr. Kaswadi, M.Hum. Materi ke-4 Media Pembelajaran Interaktif disampaikan Rini Damayanti, S.Pd, M.Hum dan matri ke-5 terkait evaluasi berbasis teknologi disampaikan Dr. Sueb, M.Pd. Pembelrian materi disambut antusiasme guru. Hal ini sangat menarik bagi guru-guru yang memiliki latar belakang pendidikan beragam mulai dari Teknik, MIPA, dan juga sosial/sastra.Kegiatan dilanjutkan dengan sesi tanya jawab.

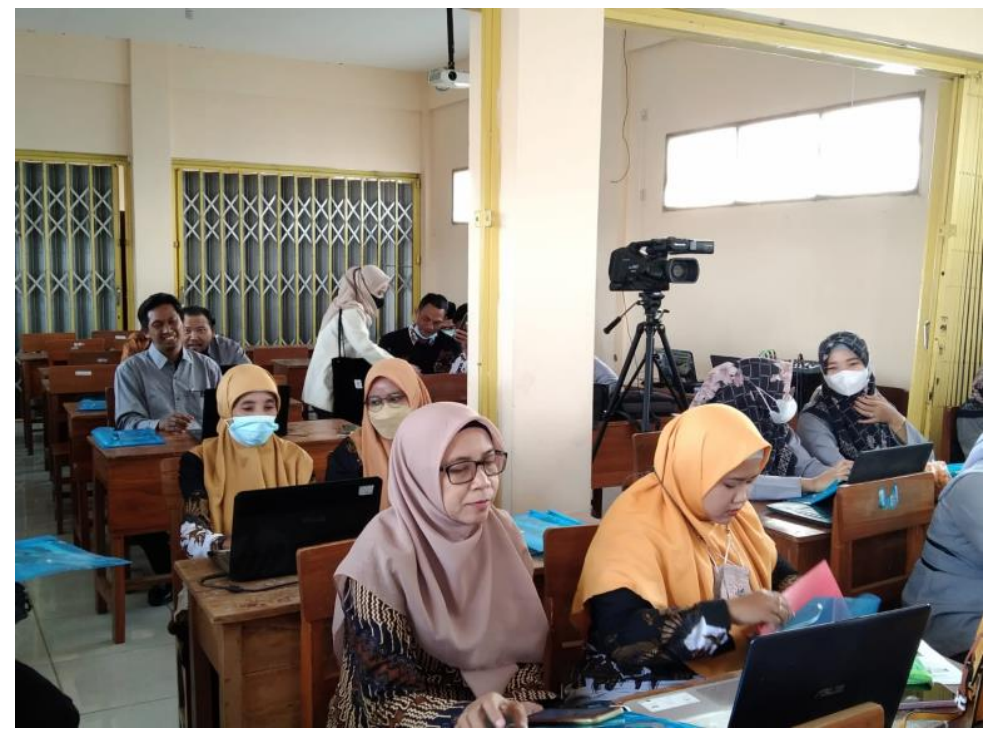

Gambar 2. Praktik penyusunan perangkat pembelajaran berbasis IT

Berdasarkan hasil diskusi, tanya jawab, serta pengamatan selama proses kegiatan berlangsung, kegiatan ini mendapat respon positif. Hal ini dapat dilihat dari antusiasme peserta yang mengikuti pelatihan dan sosialisasi berperan aktif. Kegiatan pelatihan ini pun berjalan dengan lancar.

Setelah semua materi tersampaikan, kegiatan dilanjutkan dengan tutorial penyusunan perangkat pembelajaran. Setelah peserta melakukan presentasi, dosen pendamping memberikan masukan-masukan untuk perbaikan perangkat pembelajaran yang telah dibuat. Beberapa kesalahan yang ditemui dalam sesi ini yaitu kesalahan pemilihan media, kesalahan dalam sistematika penulisan, dan adanya guru yang masih kurang paham 
tentang prosedur penilaian. Kegiatan pendampingan melalui tatap muka antara dosen dan peserta pelatihan.

Kendala dalam pelatihan ini berupa pembuatan perangkat pembelajaran bagi guru memang tidak mudah, mengingat guru diberi beban mengajar minimal 24 jam perminggu. Selain itu tugas yang diemban oleh pendidik dan pengajar untuk berperan dalam kegiatan sosial kemasyarakatan yang menumpuk. Lebih dari sekedar pemenuhan persyaratan kenaikan pangkat/jabatan, menulis karya ilmiah dan berbagai kegiatan pengembangan profesi lainnya sebaiknya senantiasa dilakukan oleh para guru sebagai anggota profesi. Profesi apapun, kemapanan dan kematangannya sangat bergantung pada "kiprah" anggotanya (Tukiran, 2012).

Sebagai contoh, tinggi rendahnya pengakuan dan penghargaan masyarakat terhadap profesi guru sangat tergantung dari profesionalitas guru dalam melaksanakan tugasnya. Suherli (2012) menyatakan tugas guru yaitu mendidik, mengajar, sedang dari sisi hasil yaitu berbagai jenis karya tulis ilmiah guru seperti buku pelajaran, modul, artikel, laporan penelitian, media pendidikan, diktat dan lain-lain yang sangat bermanfaat bagi dunia pendidikan. Berbagai karya guru tersebut akan menguatkan eksistensi profesi guru. Dengan demikian, kegiatan pengembangan profesi, dalam hal ini menulis karya tulis ilmiah hendaknya dipandang sebagai bagian integral tugas, kewajiban, dan tangung jawab setiap guru.

Setelah diberikan pelatihan oleh tim penmas PBSI UWKS, para peserta mulai bisa menyusun perangkat pembelajaran yang lebih efektif. Hal ini dapat diketahui dari hasil pelatihan pembuatan perangkat pembelajaran untuk meningkatkan profesi bagi guru. Selain itu para guru mengaku memahami mengapa seorang guru wajib membuat perangkat pembelajaran bukan merupakan beban tapi merupakan suatu kewajiban. Pemberian masukan berupa ide dan saran akademik bertalian dengan penyempurnaan perangkat pembelajaran bagi guru-guru di Yayasan Tanada mulai dari tahap perencanaan sampai refleksi sangat didukung dengan baik. Tuntutan profesi guru untuk membuat perangkat pembelajaran dalam rangka meningkatkan profesionalisme guru dan tuntutan dari Dinas Pendidikan untuk mendukung kenaikan jabatan dan golongan yang akan naik pangkat yang lebih tinggi.

\section{Simpulan dan Tindak Lanjut}

Simpulan akhir dari pelaksanaan program pengabdian masyarakat "Workshop Strategi Penyusunan Perangkat Pembelajaran Berbasis IT sebagai Upaya Efisiensi dan Efektivitas Tugas Guru di Yayasan Tanada Waru Sidoarjo" ialah:

1. Meningkatnya kemauan peserta dalam membuat perangkat pembelajaran berupa silabus, RPP, Lembar Kegiatan Siswa (LKS), Instrumen Evaluasi atau Tes Hasil Belajar (THB), serta Media Alat Peraga pembelajaran dan terintegrasi dengan IT

2. Meningkatnya kemampuan peserta dalam membuat perangkat pembelajaran berbasis IT meliputi kemampuan: Menyusun RPP, Menyusun bahan ajar dan media pembelajaran berbasis teknologi, Membuat alat evaluasi yang mempergunakan teknologi,

3. Meningkatnya kemampuan mengintegrasikan IT pada pembelajaran 
Rencana tindak lanjut akan diadakan kegiatan pelatihan blended learning dengan mengaplikasikan perangkat pembelajaran berbasis IT yang telah dibuat pada pelatihan kali ini dengan menghadirkan narasumber dari UWKS yang dapat dipergunakan untuk kenaikan karir atau jabatan bagi guru.

\section{Daftar Pustaka}

Berlin, S. (2014). Strategi Pembelajaran didalam Kelas. Bandung : Alfabeta

Depdiknas Dirjen Dikdasmen Direktorat Tenaga Kependidikan. (2001). Pedoman Penyusunan Karya Tulis Ilmiah di Bidang Pendidikan dan Angka Kredit Pengembangan Profesi Guru. Jakarta

Kunandar, K. (2007). Guru Profesional : Implementasi Kurikulum Tingkat Satuan Pendidikan (KTSP) dan Sukses dalam Sertifikasi Guru. Jakarta : Rajagrafindo Persada.

Majid, A. (2011). Perencanaan Pembelajaran Mengembangkan Kompetensi. Guru. Bandung: PT Remaja Rosda Karya

Mahsun, M. (2011). Metode Penelitian Bahasa (Tahapan, Strategi, Metode, dan Tekniknya). Jakarta: Rajawali Pers

Mulyasa, M. (2008). Kurikulum Tingkat Satuan Pendidikan. Bandung : Remaja Rosdakarya.

Trianto, T. (2007). Model-model Pembelajaran ilnovatif berorientasi kontruktivistik. Jakarta: Prestasi Pustaka

Rosmiati, A. (2019). Dasar-dasar Penulisan Karya Ilmiah. Surakarta : Isi Press.

Sudarwan, D. (2013). Karya Tulis Inovatif Sebuah Pengembangan Profesi Guru. Bandung : PT Remaja Rosdakarya

Sudjana, N. (2000). Dasar-Dasar Proses Belajar Mengajar. Bandung: Sinar Baru Algensindo

Suherli, K. (2012). Merancang Karya Tulis Ilmiah. Bandung : PT Remaja Rosdakarya.

Usman, M. U. (2001). Menjadi Guru Profesional. Bandung: Remaja Rosdakarya.

Wahyu, W. (2001). Managemen Bahasa Pengorganisasian Karangan Pragmatik dalam Bahasa Indonesia untuk Mahasiswa dan Praktisi Bisnis. Jakarta: Gramedia Pustaka Utama

Yudha, C. B., \& Rahmad , I. N. (2020). PELATIHAN PENULISAAN PENELITIAN TINDAKAN KELAS (PTK) PADA GURU SDN CIBITUNG KULON 01 BOGOR. Mitra Mahajana: Jurnal Pengabdian Masyarakat, 1(1), 20-23. https://doi.org/10.37478/mahajana.v1i1.714 